\title{
THE REWARDS \& CHALLENGES OF COLLABORATIVE WORKS WITH A TOP-TIER UNIVERSITY IN AFRICA
}

PURDUE

FORT WAYNE

\author{
K. S. Isiorho, PhD, MBA, CPG, LPG \\ Emeritus Prof of Geosciences \\ Biology Dept., Purdue University Fort Wayne (PFW), \\ $\&$ \\ D. O. Omole, PhD, MPA, PE \\ Professor \& Dean, College of Engineering, \\ Covenant University, Ota, Ogun State, Nigeria
}

Presented at the National GSA meeting , Phoenix AZ, Sept. 22, 2019 


\section{In the beginning}

- Undergraduate training

- Research work(s)

- Doctorial research work

- Earthwatch/National Geographic field work

- Return to Africa

- Sabbatical 2009
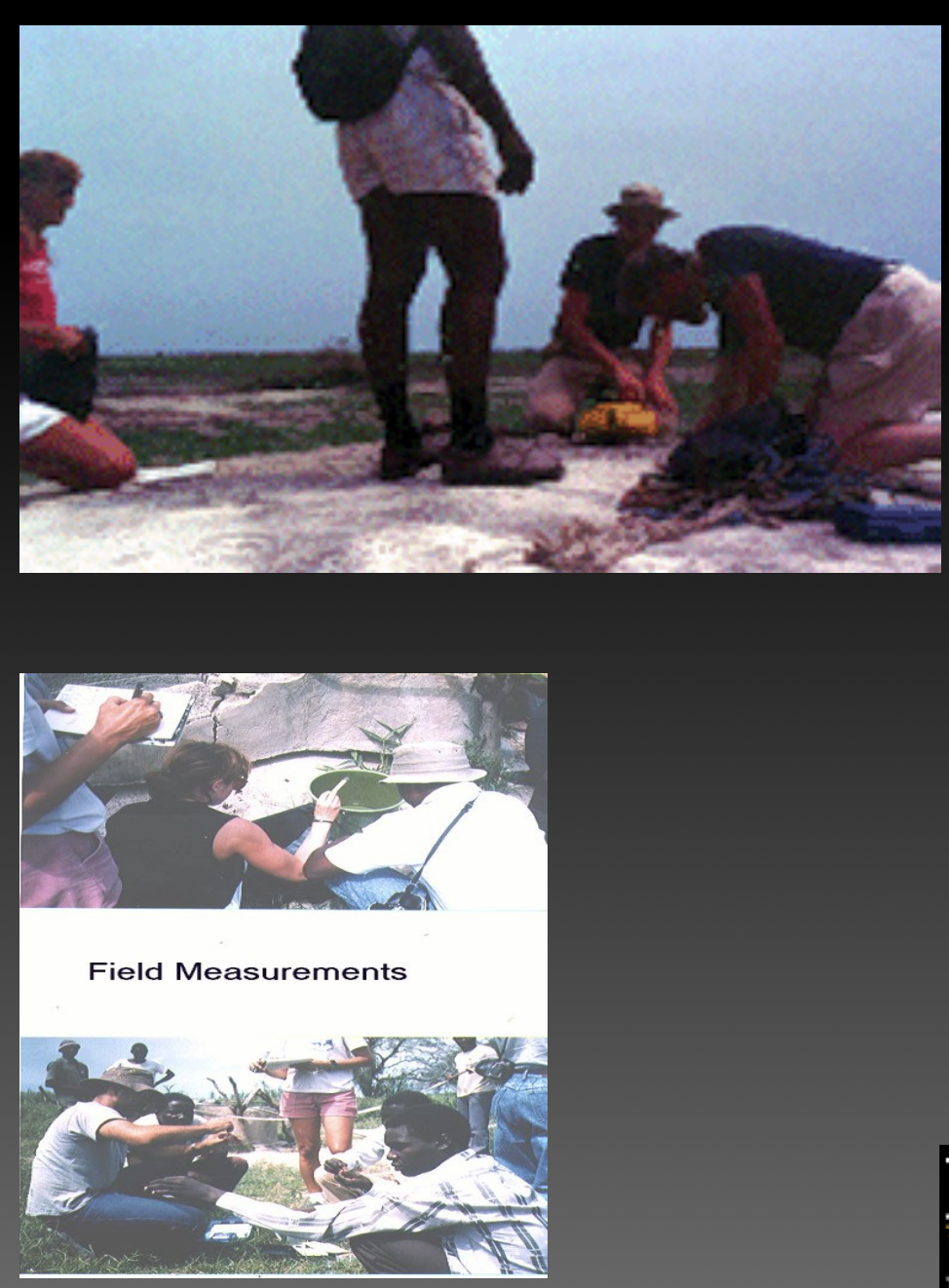
- Preparation

- Schools visited

- Cape Town University, South Africa (ZA)

- Calabar University, Nigeria

- Delta State University, Nigeria

- An invitation to Covenant University

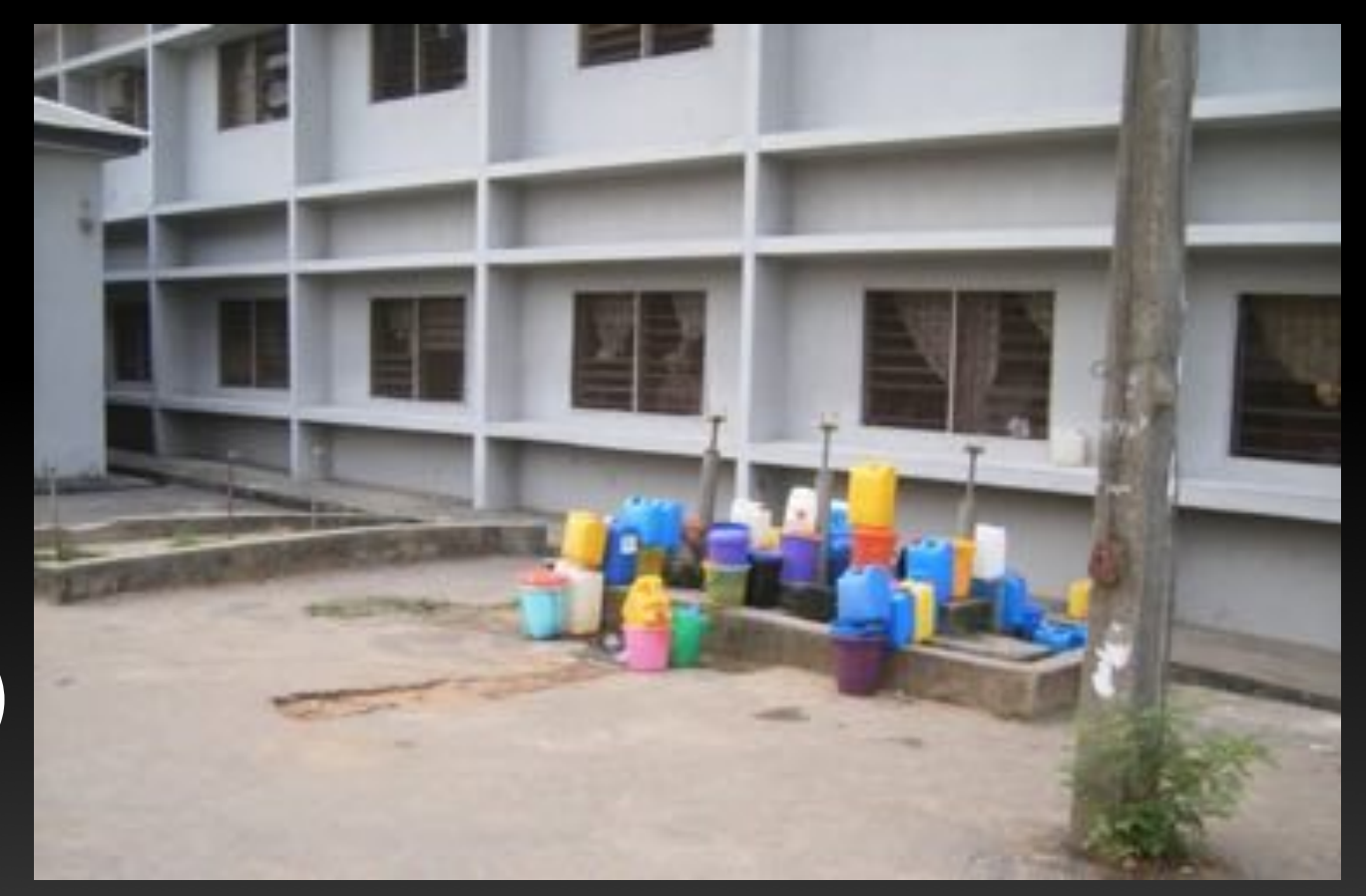




\section{Covenant University (CU)}

- CU is a private university in Nigeria with a 15,000 student population; established 2002

- CU Ranking ... is ranked fourth best university in Africa and the best university in Nigeria as of 2018. "According to Professor Okebukola, universities were ranked by several indicators of academic or research performance, including alumni and staff winning Nobel Prizes and Fields Medals, highly cited researchers, papers published in Nature and Science, papers indexed in major citation indices, and the per capita academic performance of an institution." Accessed Aug 18, 2019 https://covenantuniversity.edu.ng/News/Okebukola-Lauds-Covenant-Expects-More-AfricanVarsities-in-World-Rankings\#.XVta8a2ZNOI

"Vice-Chancellor, Chrisland University, ...... could vouch for Covenant as the best University in Nigeria and Africa." (-)

\section{... chairs provide topics to be covered.}

- Topics covered ...remote sensing in hydrogeology, soil water interaction, earth structure with a culmination of a town-gown presentation 


\section{Examples of topics covered in Civil Engineering}

Earth processes observed within the campus were incorporated in some lectures presented to the students.

- "Lecture Schedule at the Department of Civil Engineering for Prof. Solomon Isiorho (Visiting Professor)

- S/No. Date

- 1 Tue 19th Feb 2019

- 2 Tue 19th Feb 2019

- 3 Fri 22nd Feb 2019

- 4 Tue 26th Feb 2019

- 5 Tue 26th Feb 2019

- $6 \quad$ Fri 1st Mar 2019

$\begin{array}{ll}\text { Time } & \text { Course } \\ \text { 1-2 pm } & \text { CVE322 } \\ \text { 2-3 pm } & \text { CVE322 }\end{array}$

$11-2$ pm CVw824/CVW924

1-2 pm CVE322

2-3 pm CVE322

12-3 pm CVG820/CVG920 $\underline{\text { Topic }}$

Origin of Soils - Rocks and Minerals

Formation of soil - Weathering processes, transportation, environment of deposition

Groundwater flow - Aquifer properties and

\section{Geologic structure}




\section{Physics: Hydrogeology....remote sensing \& geophysics in hydrology...}

lectures, videos, reading assignments...class met 3 to 6 hours

- Read and write a one-page report on the following six articles. Your review should include a paragraph of your opinion and take away of each article.

- 1. Introduction to groundwater physics by M. Anderson DUE

- 2. Measuring methods for groundwater - surface water ... a review DUE

- 3. Errors with small volume elastic sample bags. DUE

- 4. Measuring

- 5. In-ground dispersal of

- 6. Deciding alternative

options in a watershed using GIS. DUE
Wetland and hydrology DUE

: The Science of getting water into the ground DUE

PURDUE

FORT WAYNE 


\section{- Campus materials used in lectures... weathering}
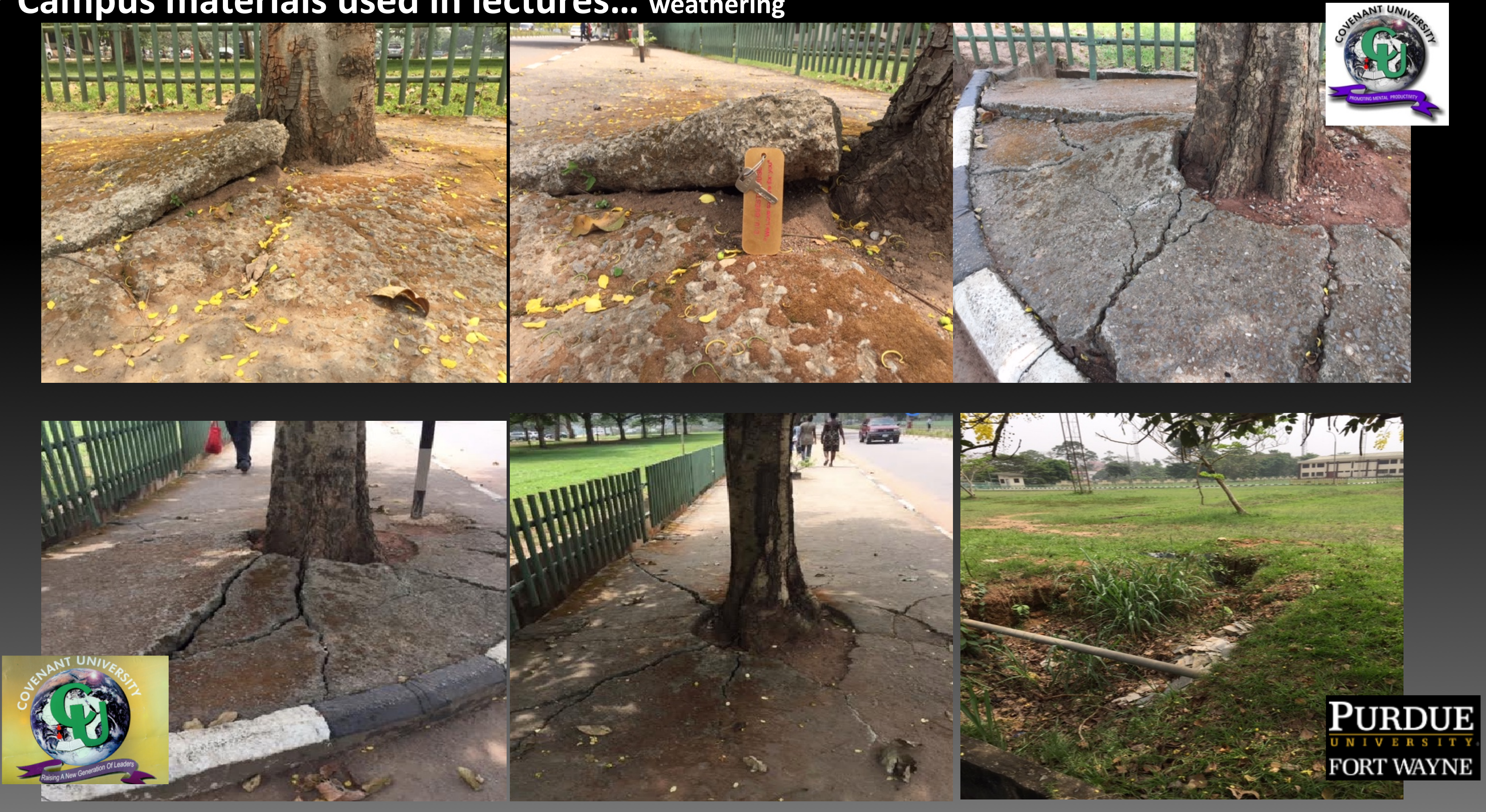


\section{Covenant University}

- Town-gown presentation
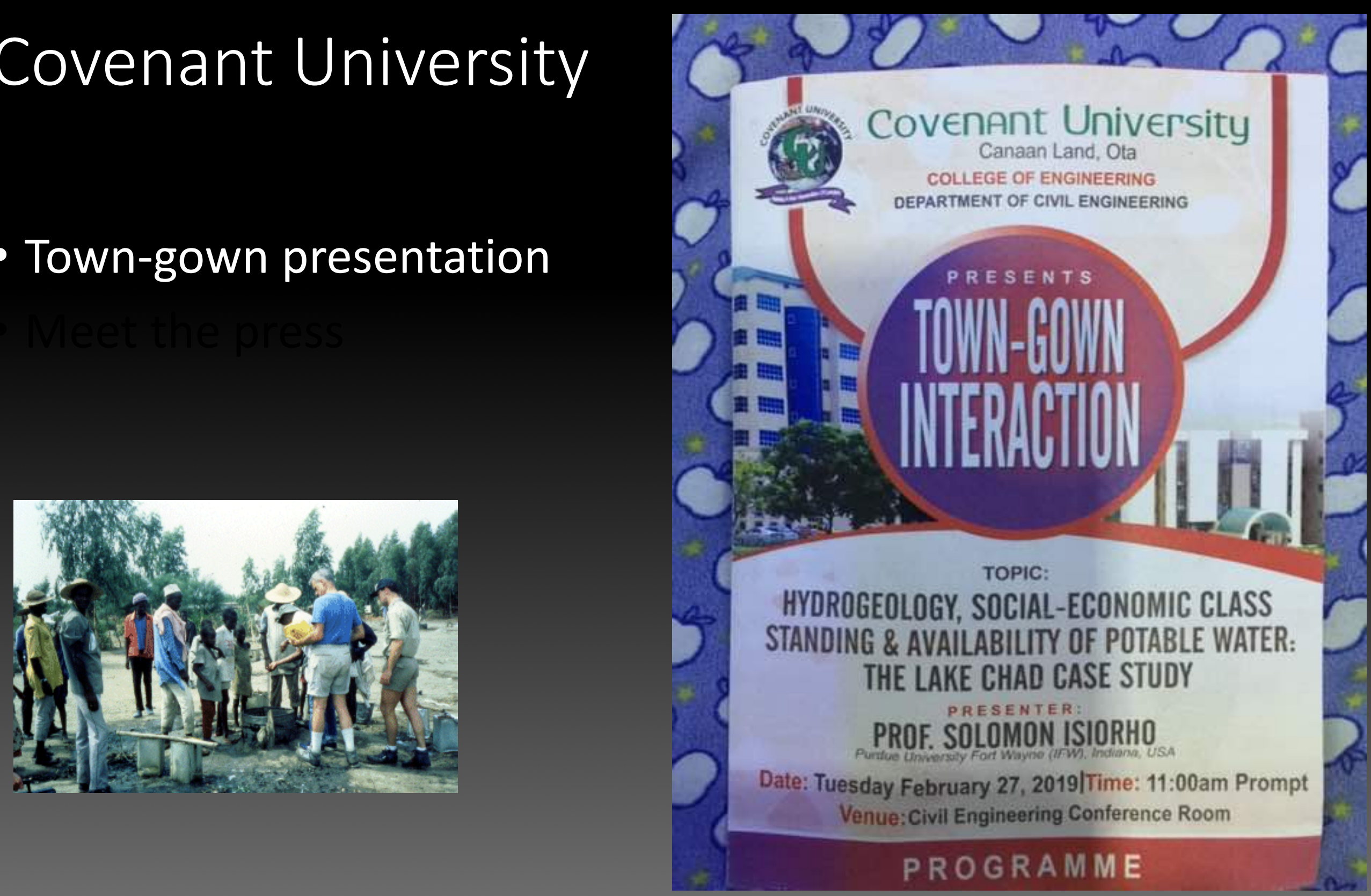


\section{Covenant University}

- Meet the press

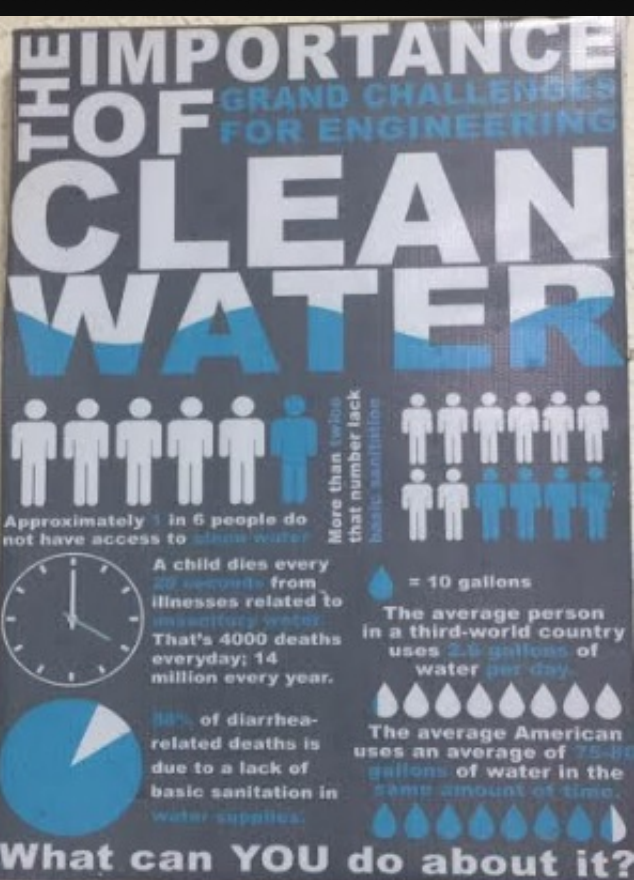

Education Paramount to Facilitate Water for All, Says Expert

People at the different levels of the social strata should be exposed to the dos and don'ts of water conservation so as to ensure easy access to clean water for the generality, an emeritus Professor of Geoscience at Burdue University, USA, Professor King S. Isiorho, has declared.

Professor Isiorho, who was Guest Speaker at the Town and Gown Seminar of the Department of Civil Engineering, Covenant, held on Wednesday, February 27, 2019, said that water was a gift for all and not a commodity to be sold, hence there was the need to involve stakeholders in addressing issues around its accessibility.

The Guest Speaker, while making a presentation with the topic, 'Hydrogeology, Social-Economic Class Standing and Availability of Potable Water: The Lake Chad Case Study',

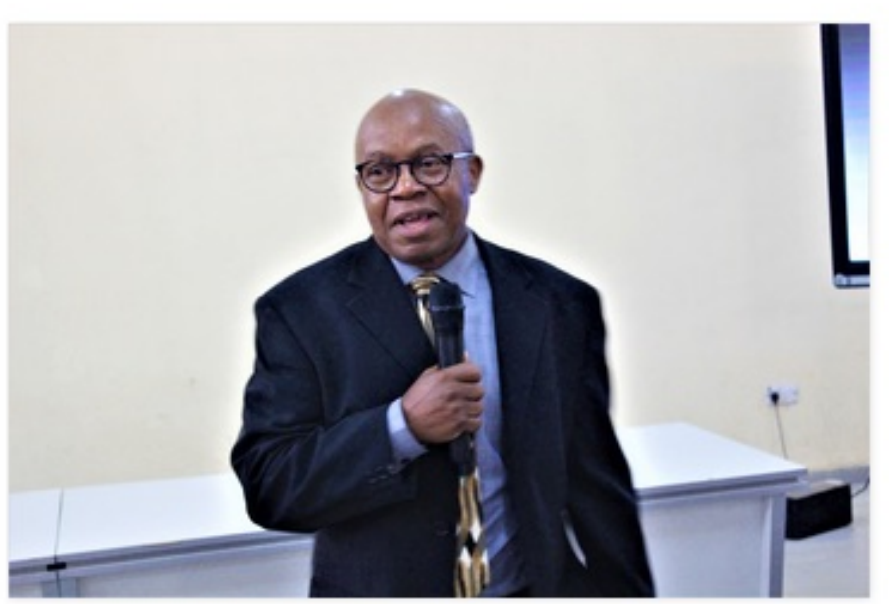

Professor Solomon Isiorho from Indiana University-Purdue University Fort Wayne, USA, making his presentation at the Department of Civil Engineering's Town and Gown Seminar

asserted that status affected access to water.

He said that the Lake Chad, which is in Borno State, Northern Nigeria, and shared by Nigeria, Chad, Cameroun and the Niger Republic, was very important in that it was a source of protein (fish), a means of transportation, a source of water for about 30 million people, and a habitat for people to live because of the land that surrounded it.

While speaking on the procurement of water, gender and the labour involved, Professor Isiorho said that water could be good just from the well, and women went long distances to get water in the northern part of Lake Chad. Pertaining to the socioeconomic class standing in the procurement of water, he explained that the poorer a people, the poorer the quality of water they got. "Moving up the social ladder, we have bore holes. When you are up there, you buy bottled water," he stated. 


\section{- Meet the press}

About Us

Admissions

Colleges

Library News Research

Home

It Like 0 Tweet +4 Share 1

Covenant Environment Conducive to Research and Learning - Scholar

Covenant's burgeoning status as a research University has received acknowledgment from another of her International Visiting Scholars, Professor Solomon Isiorho, who asserted that the atmosphere at the University and her facilities were very conducive to research and leaming.

According to the Professor of Geo-Sciences from the University of Purdue, Indiana, USA, on each of the occasions that he had been to Covenant, he was always amazed because the

University always had something new. "I have often told folks that this environment is so inviting, tranquil and conducive to

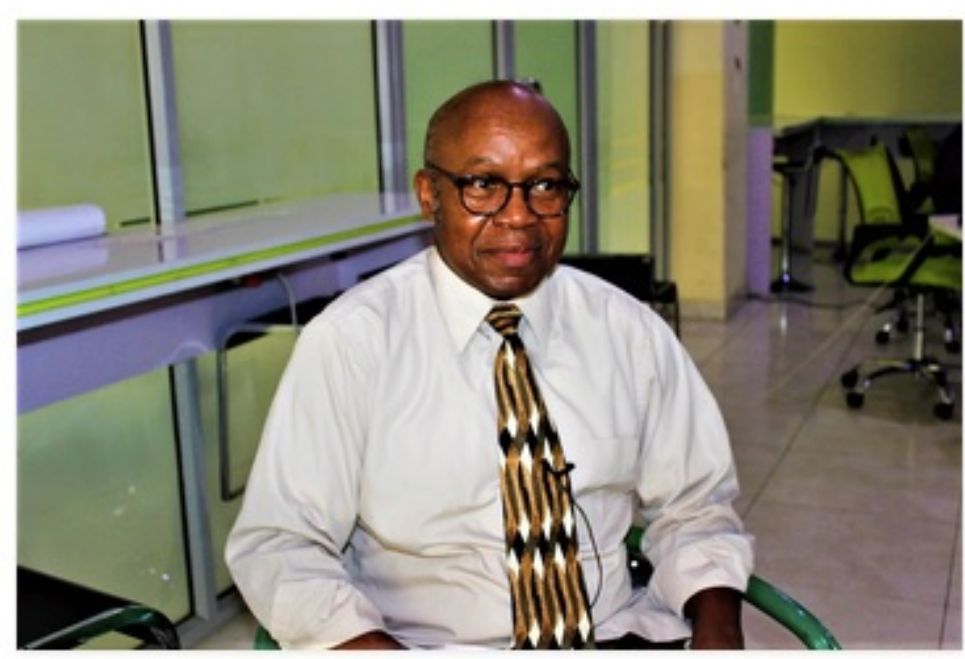




\section{My impression}

- Both undergrad and graduate students were eager to discuss their ongoing research/plausible research topics. Plans on collaborating on some applied research projects were discussed with the professors.

- The availability of equipment/instruments are some of the major concerns in some of these universities. Despite the limited availability of equipment and heavy teaching load, the faculty have high research productivity with several publications in top-tier international journals; some of the faculty have several awards (national \& international)

- AGU 2018 "Africa Award for Research Excellence in Earth Science Ahzegbobor Philips Aizebeokhai, Covenant University, Ota, Nigeria" 
- What's it like at CU?

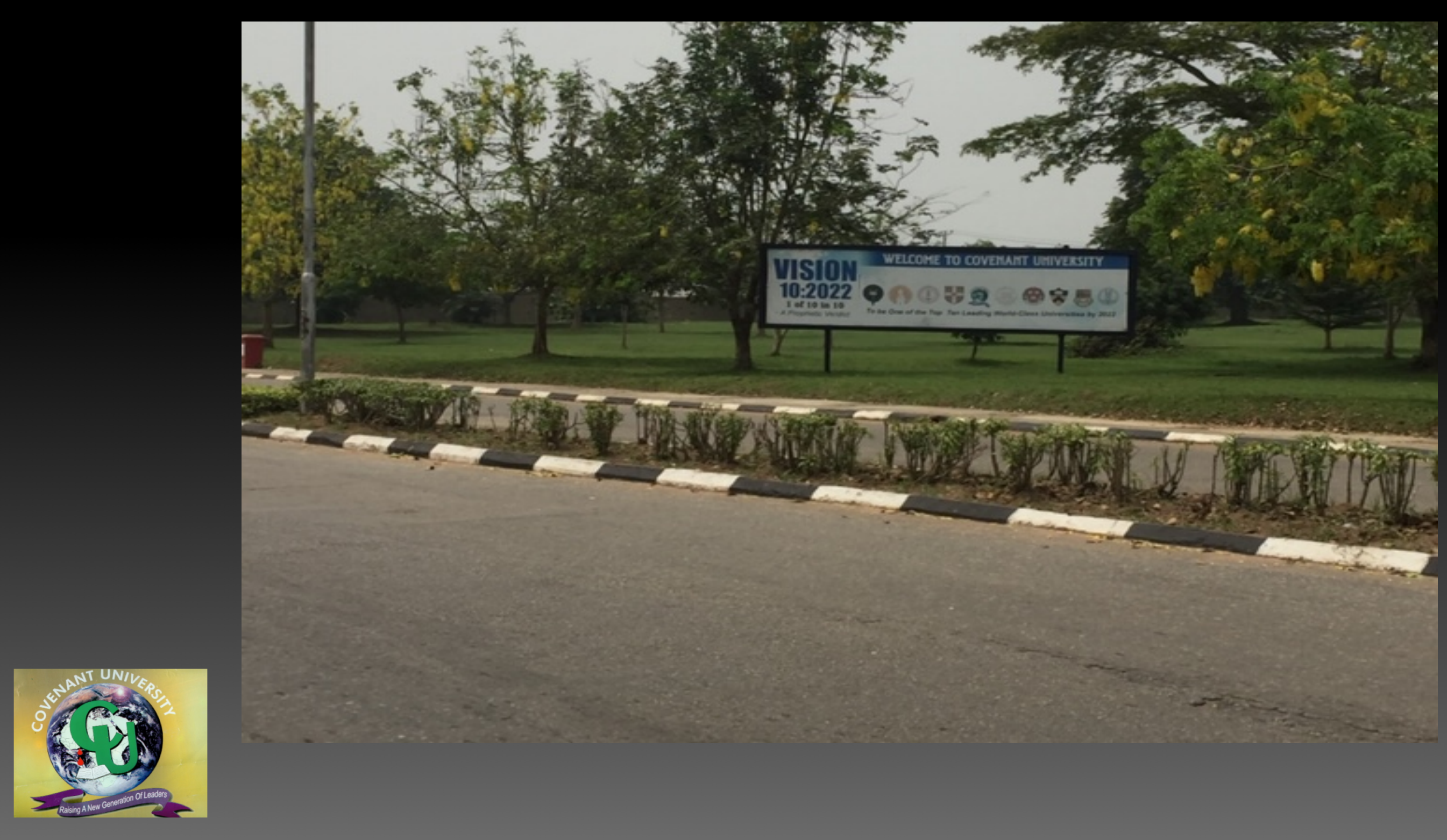

PURDUE

UN I VERSITY

FORT WAYNE 
- What's it like at CU?... Beautiful landscape \& security
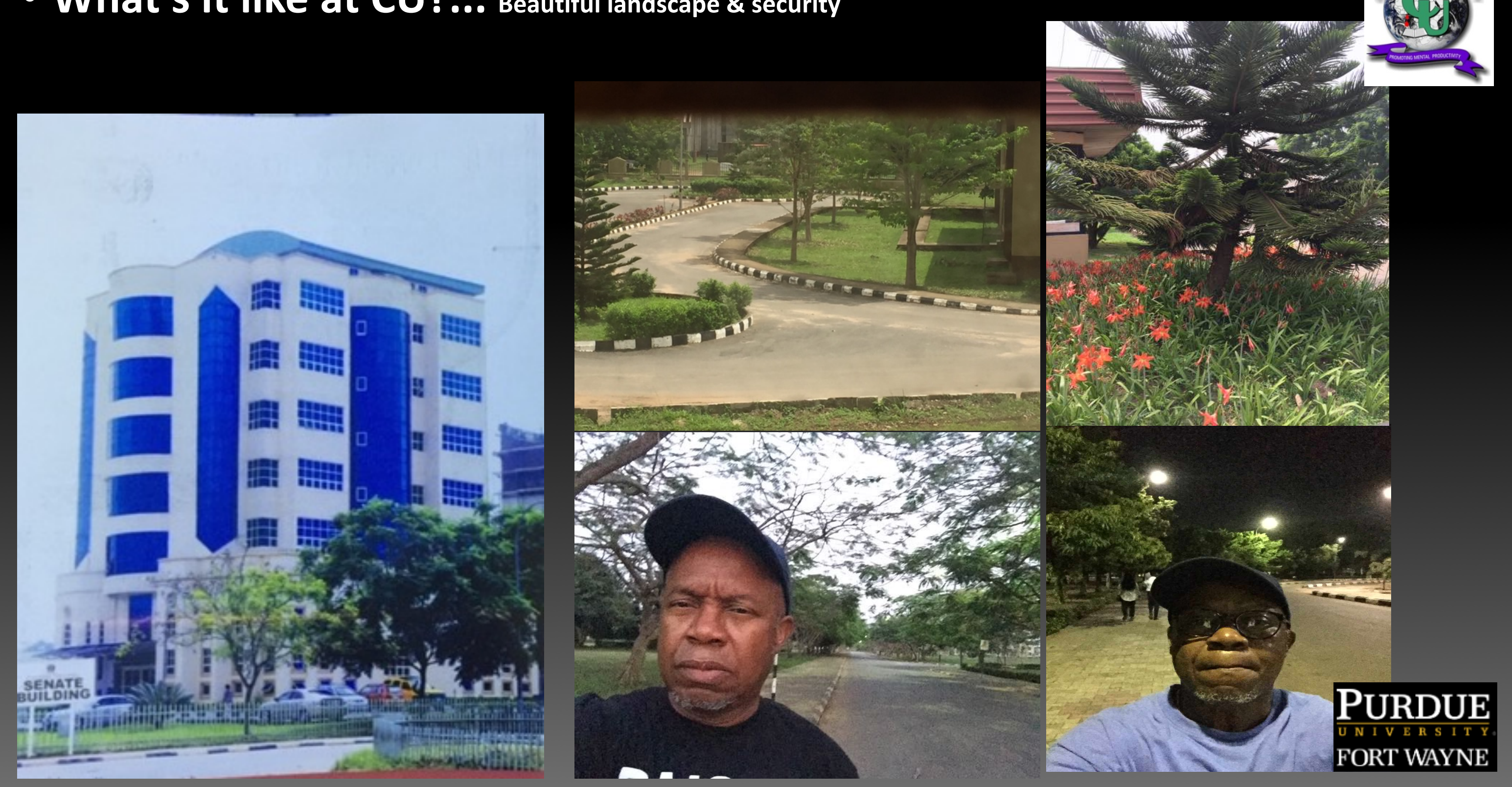
- What's it like at CU?... class rooms, dorms, guest house $\&$ sports arena
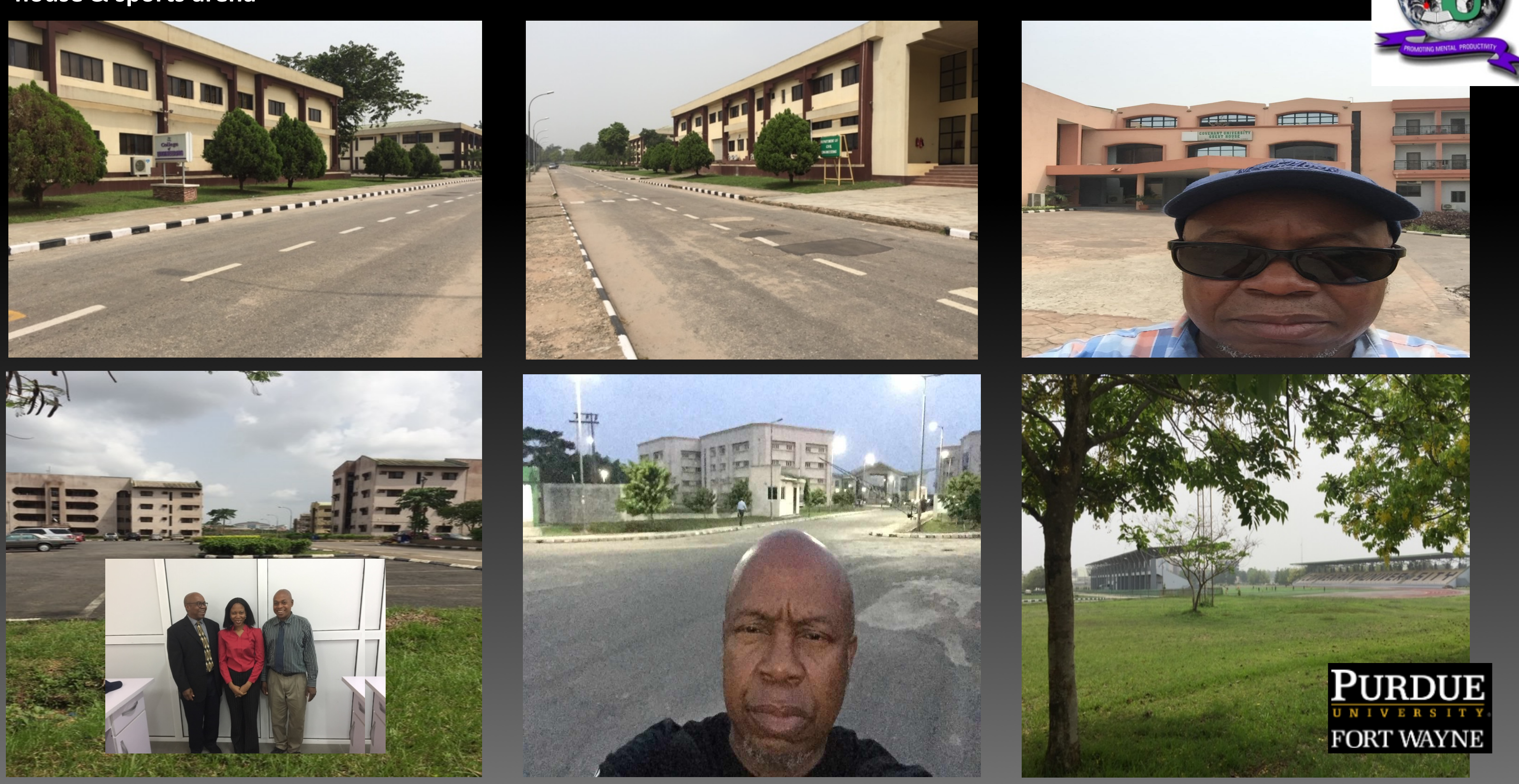


\section{REWARDS \& CHALLENGES}

New places \& Expansion of horizons

Make positive difference in students \& colleagues lives

Make the world a better place

For Americans, security concerns

Patience ... heavy dose
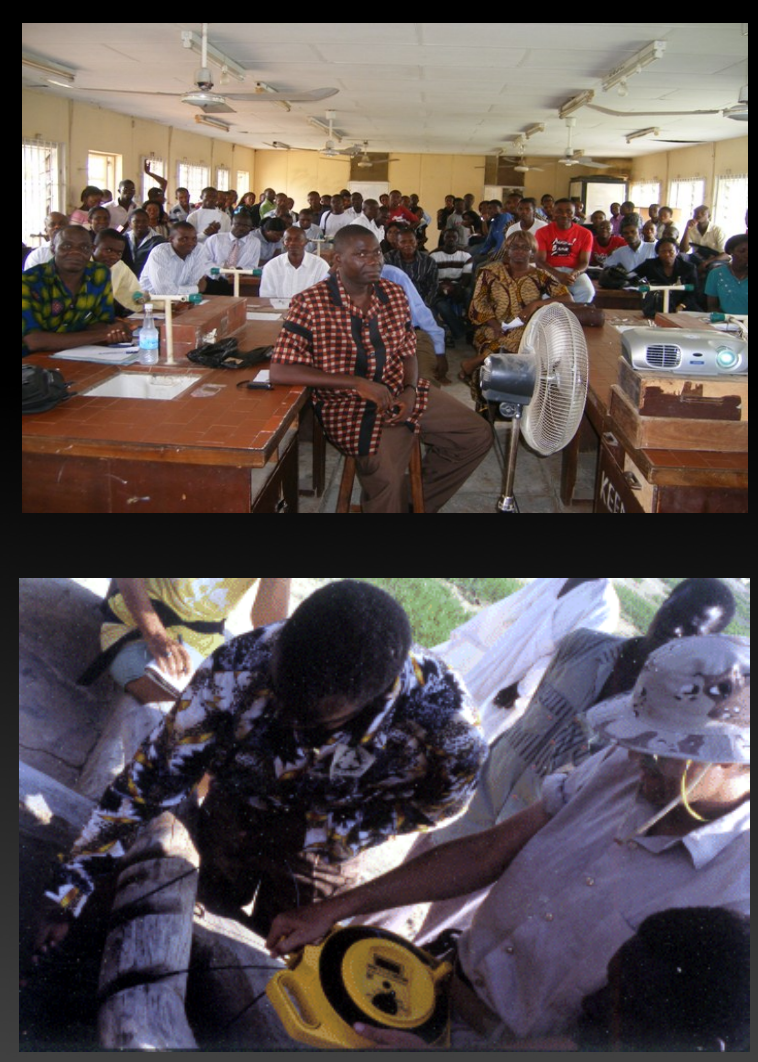


\section{Some collaborative works/presentations}

- Omole D. O., Isiorho, S. A., and Ndambuki, J. M., 2016, Waste management practices in Nigeria: Impacts and mitigation, in Wessel, G. R., and Greenberg, J. K., eds. Geoscience for the Public Good and Global Development: Toward a Sustainable Future: Geological Society of America Special Paper 520, p. 377-386, doi:10.1130/2016.2520(33). - Isiorho, S. A., Omole, D. O, and Aizebeokhai, P. A., 2016, Increasing the success rate of groundwater exploration in developing nation using geophysical methods: Case of a small
community in Nigeria. Poster presentation (Dec 12) at the Fall AGU meeting, San Francisco, CA, USA, December 11-16, 2016

- Omole, David O., Isiorho, Solomon A., *Tenebe, Theophilus and *Emenike, PraiseGod. 2015, Student emersion in engineering and geosciences research: one-way of strengthening the disciplines. Geological Society of Ämerica Abstracts with Programs. Vol. 47, No. 7, p. 87

- Isiorho, S.A., Omole, D.O., Ogbiye, A.S., Olukanni, D.O., Ede, A.N., and Akinwumi, I.I., 2014, Study of ReedBed of an Úrban Wastewater in a Nigerian Community. Proceeding of IASTED's Environmental Management and Engineering (EME 2014) Conference, held in Banff, Canada (July 16 through July 18, 2014), p. 143-147. (Scopus Indexed).

- Oginni F. A., and Isiorho S. A., 2014, Evaluation of a constructed wetland for removal of some physicochemical and microbiological contaminants from wastewater in a residential tertiary Institution in Nigeria. Agric Eng. Int: CIGR Journal, 16 (3): 1-9. 
Several Reputable Foreign Scholars Join Covenant as International Visiting Scholars

Covenant, West Africa's pre-eminent University and one of the top 10 in Africa, has continued to prove to be the preferred destination for many foreign scholars, courtesy of the University's fast rising profile as a research and leaming institution of repute.

The foreign Scholars, whose nationalities cut across different parts of the world, namely Europe, America, Asia and the Far East, have joined Covenant as International Visiting Scholars.

The appointment of International Visiting Scholars at Covenant is renewable each academic session. Each stay is an opportunity for scholars to engage in teaching, scholarly scientific life of the University community, and possible research collaborations with members of the faculty in the

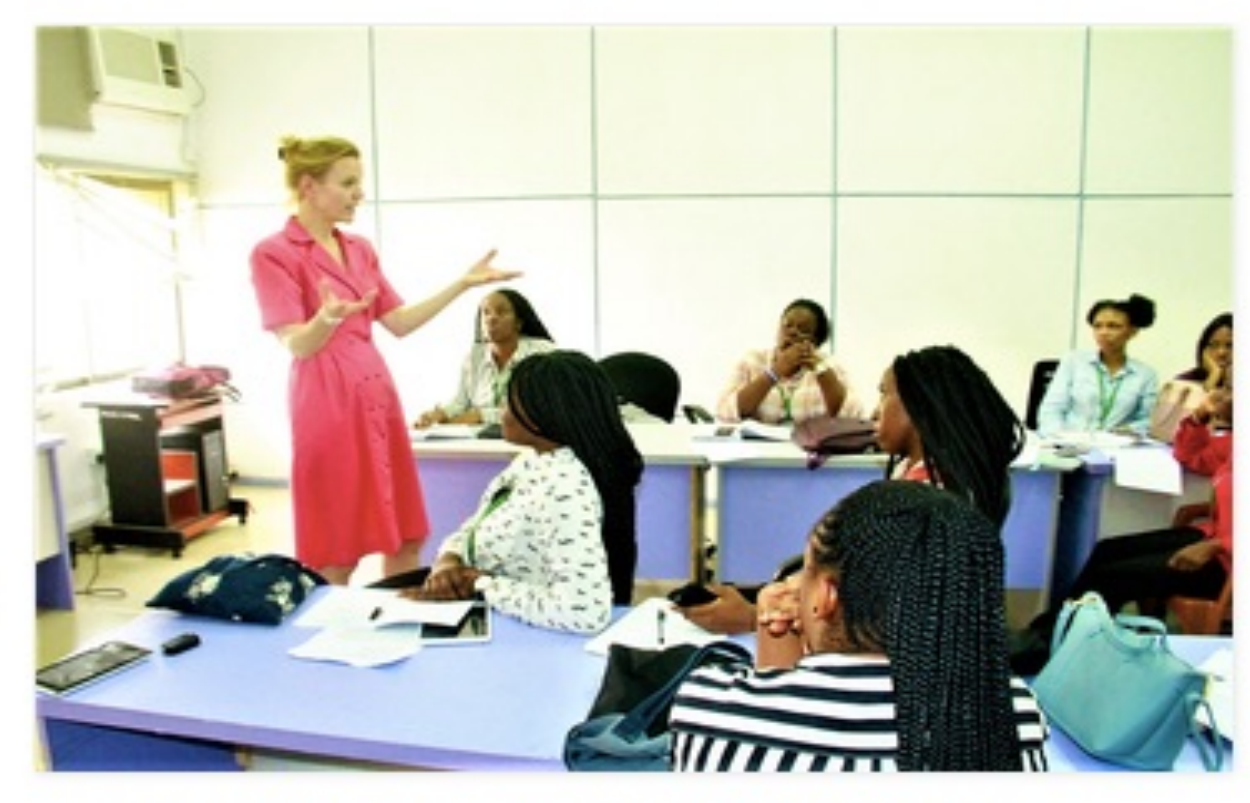

Dr. Loes Damhof in Covenant as International Visiting Scholar receiving Department.

Indeed, Covenant had long established the culture of receiving international scholars, but the surge in number validates the recent elevation in status, particularly the University's ranking as a world-class institution prompted by a drastic improvement in her research endeavours, cutting edge teaching and world outlook.

PURDUE UNIVERSITY FORT WAYNE 


\section{Acknowledgement}

- The chairs of Civil and Petroleum Engineering departments, (Ede, A.N \& Orodu, O. D)

- Chair of Physics Department (Aizebeokhai, P.A)

- Director of International Office \& Linkages (Peter Ada)

- The management at Covenant University , Ota, Ogun State, Nigeria

- https://www.covenantuniversity.edu.ng/About-Us/Our-Core-Values\#.XYKrfK2ZOIY 

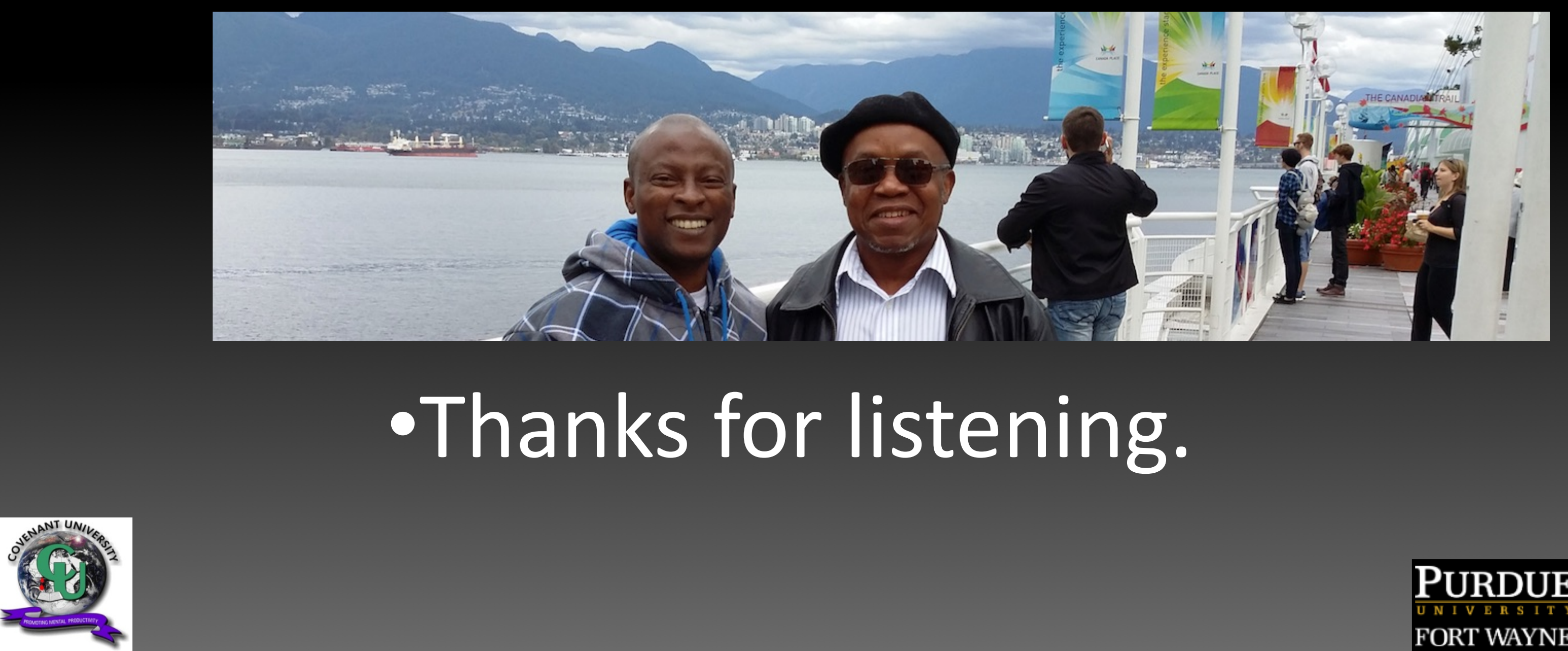

PURDUE

UNIVERSITY

FORT WAYNE 